\title{
LEAN TEAM MEMBERS' SELECTION FOR PUBLIC ADMINISTRATION ORGANISATIONS
}

\section{Olga Leontjeva}

Ph.D (in Public administration), University of Latvia. Address: Aspazijas boulevard 5, Riga, LV-1050, Latvia

E-mail: olga.leontjeva@dr.com

\section{Valeria Trufanova}

MSc. student, National Research University Higher School of Economics. Address: Myasnitskaya st., 20, Moscow, 101000, Russian Federation.

E-mail: vvtrufanova_3@edu.hse.ru

\section{Abstract}

Public administration organisations in some countries, while focusing on project implementation through innovative approaches, are starting to apply an organisational matrix structure. This approach involves the adaptation of Lean in public administration by creating a model for rational project team members' selection in public administration organisations. To examine this relatively new tool for public administration organisations, the authors base their research on the public administration organizations of Latvia and Russia and their employees by reporting the results of several studies.

This interest in the Lean concept and its application in public administration, particularly in the sphere of human resource management activities, has been supported by the analysis of data retrieved from studies by the authors (primary quantitative and qualitative data analysis) and other researchers (secondary quantitative and qualitative data analysis) on public administration employees' competences and personal preferences in Latvia and Russia. The article includes a comparison of personal preference identification concepts by various researchers (monographic research). Finally, the authors demonstrate the developed model, providing a detailed description and application guidelines. The authors conclude that the model's application should be supported by its integration into a public administration employees' performance assessment (by competences) system such as NEVIS which is used in Latvia.

Public administration organisations can implement the proposed model, which is an example of the rational project team selection approach. The model considers both the competences and personal preferences of the potential project team members. The project team members' selection process model also includes a mathematical decision-making model for solving optimisation tasks based on linear programming.

Keywords: Public Administration, Occupational Competencies, Personal Preferences, Human Resource Recruitment and Selection, Lean.

Citation: Leontjeva O. \& Trufanova, V. (2018). Lean Team Members' Selection for Public Administration Organisations. Public Administration Issues, Special Issue II (electronic edition), pp. 45-65 (in English); DOI: 10.17323/1999-5431-2018-0-6-45-64 


\section{Introduction}

Human Resource Management (HRM) or a relevant course (e.g. Personnel Management) as well as Project Management courses are a popular part of Public Administration (PA) study programs by various European tertiary education institutions (Voronchuk, and Starineca, 2014).

Project team management as well as project team creation and development is sometimes a topic of an HRM course. Students are often curious about the applicable approaches of rational project team members' selection during HRM courses. There are various approaches that can be applied by public administration practitioners, however, the authors of this paper would like to focus on those which are focused on a competence-based approach (Starineca \& Voronchuk, 2015), because PA practitioners develop a competence model as a tool for the implementation of various HRM activities (Ministerstvo truda i..., 2013; Ministru kabinets, 2012).

The aim of the research is to develop a rational approach to project team member selection, considering the tendencies of PA organisations to apply Lean to managerial processes, and use a competence model and matrix organisational structure (to be able to succeed in project-oriented activities). The objective of the research is to develop a project team members' selection model for PA organisations. The developed model should be a tool that can be proposed to PA practitioners who are dealing with project team creation. The authors of the present paper set several research tasks:

1. Literature review on new public management and Lean in public administration (Chapter 3) to identify the tendencies in public administration HRM and collect information on the actual concepts which should be considered when developing the model.

2. Literature review on public administration employees' personal preferences and competences (Chapters 4 and 5) to collect information about these two criteria for employees' selection for a job.

3. Summarise and interpret analysis of primary and secondary data on public administration employees' personal preferences and competences using research results in the case of Russia and Latvia (chapter 4 and 5) to support the idea that both are modern criteria used by practitioners selecting employees for a job.

4. Develop and describe a project team members' selection model for public administration organisations (chapter 6).

The authors will highlight applicability and limitations of the developed model.

\section{Methodology}

The authors applied a literature review and used the data from several surveys in the case of Russia and Latvia to find empirical evidence for the topicality of the approaches used to develop the project team members' selection model.

Table 1 presents a summary of the survey data used for the research. Four surveys were used. Three of them were conducted by the authors of the present 
paper, one was conducted by the Foundation "Baltic Institute of Social Sciences" and "O.D.A." Ltd (Baltic Institute of..., 2015). The data about Russia were used in Chapter 4, while the data about Latvia were used in Chapter 5.

Table 1

\section{Summary of the survey data used for the research}

\begin{tabular}{|c|c|c|c|c|}
\hline $\begin{array}{l}\text { Survey } \\
\text { Data } \\
\text { on the } \\
\text { survey }\end{array}$ & $\begin{array}{c}\text { 1. Survey } \\
\text { on personal } \\
\text { preferences } \\
\text { of PA employees } \\
\text { in Russia }\end{array}$ & $\begin{array}{c}\text { 2. Survey } \\
\text { of youth studying } \\
\text { in Latvian } \\
\text { universities } \\
\text { (Baltic Institute } \\
\text { of..., 2015) }\end{array}$ & $\begin{array}{c}\text { 3. Survey } \\
\text { on PA employees' } \\
\text { competences } \\
\text { in Latvia } \\
\text { (Starineca \& } \\
\text { Voronchuk, 2016) }\end{array}$ & $\begin{array}{c}\text { 4. Survey } \\
\text { of PA study } \\
\text { programs } \\
\text { students } \\
\text { of Latvia } \\
\text { (Stariṇeca, 2017) }\end{array}$ \\
\hline $\begin{array}{l}\text { Period of data } \\
\text { collection }\end{array}$ & September 2016 & February 3-19, 2015 & $\begin{array}{l}\text { January - } \\
\text { March } 2016\end{array}$ & $\begin{array}{l}\text { October } 10,2015 \\
\text { January - } \\
\text { February } 2016 \\
\text { May 15, } 2016\end{array}$ \\
\hline Type of survey & $\begin{array}{l}\text { Self-completed } \\
\text { questionnaires } \\
\text { at study-room } \\
\text { and on-line } \\
\text { survey }\end{array}$ & $\begin{array}{l}\text { Self-completed } \\
\text { questionnaires } \\
\text { at study-room } \\
\text { and on-line survey, } \\
\text { using e-mails } \\
\text { of university students } \\
\text { and graduates }\end{array}$ & $\begin{array}{l}\text { On-line survey, } \\
\text { using e-mails } \\
\text { of the respondents }\end{array}$ & $\begin{array}{l}\text { Self-completed } \\
\text { questionnaires } \\
\text { at study-room }\end{array}$ \\
\hline $\begin{array}{l}\text { Sample } \\
\text { characteristics }\end{array}$ & $\begin{array}{l}\text { PA employees, } \\
\text { who were the } \\
\text { participants } \\
\text { of professional } \\
\text { development } \\
\text { programs } \\
\text { in Russia }\end{array}$ & $\begin{array}{l}\text { Youth aged from } \\
18 \text { to } 30 \text { years, who } \\
\text { are studying and/or } \\
\text { working in parallel } \\
\text { to the studies or have } \\
\text { finished their studies } \\
\text { during the last two } \\
\text { years and started } \\
\text { working; from } \\
13 \text { tertiary education } \\
\text { institutions of Latvia }\end{array}$ & $\begin{array}{l}\text { Human resource/ } \\
\text { personnel } \\
\text { department/unit } \\
\text { managers of the } \\
\text { ministries of the } \\
\text { Republic of Latvia }\end{array}$ & $\begin{array}{l}\text { PA or relevant } \\
\text { study program } \\
\text { postgraduate } \\
\text { students from } \\
\text { three universities } \\
\text { of Latvia }\end{array}$ \\
\hline $\begin{array}{l}\text { Achieved } \\
\text { sample size }\end{array}$ & 276 & 1685 & 12 & 29 \\
\hline $\begin{array}{l}\text { Data used for } \\
\text { the research }\end{array}$ & Primary data & Secondary data & Primary data & Primary data \\
\hline
\end{tabular}

The authors used all of the summarised theoretical information and empirical data to develop a model that is based on the Lean approach and combines both personal preferences of public administration employees and their competences. Using empirical data, the authors checked the relevance of the model development (Survey 2 and Survey 4 ) as well as defined the basic components of the model connecting basic groups of criteria (personal preferences and competences - Survey 1 and Survey 3) for PA employees' selection with the Lean approach in public administration organisations.

The authors use public administration (PA) employee as a general term that in some cases might mean civil/public servants, public officials. 


\section{New Public Management and Lean in Public Administration}

Presented in the 1970s, the New Public Management (NPM) approach in public administration is still topical and applicable (Diefenbach, 2009) despite other levels of public administration organisations functioning principle proposed - New Governance (Urmoniene \& Žukovskis, 2013). The essence of NPM is business culture/practices borrowing to organize public administration organisations functioning and make it more efficient and effective, optimizing resources i.e. "NPM is a set of assumptions and value statements about how public-sector organizations should be designed, organized, managed" (Diefenbach, 2009, p. 893). Diefenbach (2009) highlights the core idea of NPM - to make public sector organizations and their employees much more 'market-oriented' i.e. performance-, cost-, efficiency- and audit-oriented like private sector organisations. The opinions about NPM are controversial (Diefenbach, 2009), however, the authors of the present paper would like to avoid any evaluation of the advantages and disadvantages of the model and focus on the conceptual principles of it.

Public administration organisations, which use NPM, deliver services to their clients (customers) focusing on the result and measure the success by the outcome (Urmonienè \& Žukovskis, 2013). Productivity is important for the organisations in this case, and the organisations like to optimize the work of the employees. On the way towards goal-meeting, the organisations need to realize that some improvements in the working environment might take place and the implementation of new management technologies is usually a necessity. The authors of the present paper outline the connection between NPM and the Lean approach/thinking (Womack \& Jones, 2003).

The Lean approach seeks to "create more value for customers with fewer resources" (Lean Enterprise Institute, 2000-2017) and focus organisations' attention to purpose, process and people (Womack \& Jones, 2003). "Lean implementation is not a neutral and value-free activity; it is fluid and open for multiple interpretations, interests, and logics" (Pedersen \& Huniche, 2011). Lean developed basically for production is applicable also for services (Lean Enterprise Institute, 2000-2017). The authors were curious about the article by Kjærgaard et al. (n.d.) on Lean in public administration, which has a holistic view on the approach's application in PA organisations including human resource management aspects.

Pedersen \& Huniche (2011) concluded that "the processes and outcomes of Lean depend not only on the technology itself, but also the negotiation context in which the planning and implementation of lean projects take place". The balance between customers and employees service should take place implementing Lean. Employees as proficient public service deliverers require more comfortable working conditions to be able to fulfil their duties in NPM and Lean implication conditions. "They would also be more likely to experience higher psychological well-being and job satisfaction" (Pick \& Teo, 2017) especially working on change that is a typical characteristic of the NPM (Urmoniene \& Zukovskis, 2013). Hence, for further study, the authors of the present paper consider both necessary for a job - public administration employees' competences and their personal preferences. 


\section{Public Administration Employees' Personal Preferences}

Nowadays, the practice of using the methods and principles of activity optimization in the private sector is more often applied also in public sector. The concept "Lean production (manufacturing)" is already in use for solving state problems but is more commonly known as "Lean Government". Within this paper, the authors define Lean as a new way of solving operational tasks and at the same time as an innovative approach for realising the employees' potential for engagement, creativity and continuous improvement in many public organisations (Christiansen et al, 2006). In adapting these approaches to the study specifics of the administrative process management, it is necessary to rethink the behaviour of PA employees.

In the middle of the last century, Paul Henson Appleby (1952), governance theorist in democratic states, noted that despite the diversity of subjective approaches to the definition of morality, the influence of a state system on moral norms is more important than the opposite. Based on this statement Stephen K. Bailey (1964) considered that officials in the public service cannot be fully determined without consideration of a system of mental attitudes and moral qualities. The necessity of moral judgment in public administration was also described by Hendrik Wagenaar (1999) who pointed out that issues of personal morality are problem-oriented, i.e. help public servants in dealing with problems of national importance and serve as a tool of perception of facts and events of distinction in the face of uncertainty. Consequently, the allocation of PA employees' types of ethical behaviour is a requirement for Lean implementation by creating a better working environment in an operational culture.

As later noted by Christoph Demmke (2005), Professor of the European Public Service Institute, despite the numerous publications by scientists and multiple reforms of the state apparatus, there is a lack of knowledge about the relationship between organizational structure and official behaviour. Hence, the authors of the present paper discuss the theoretical arguments linking the concepts of public service motivations (PSM) and public service values (PSV). Specifically, the authors analyse the theories which can explain this connection: motivation (focus on prospects of career advancement and the opportunity to receive remuneration for work) and values (the orientation on very official activity in government as a job in the organization and display of creative expression and personal qualities).

The concept of PSM was used in 1982 to describe the motivation in the public service. Early research sought to identify PSM as an individual person's predisposition to respond to motives of their behaviour, mainly in public institutions and organizations (Perry \& Wise, 1990). Brewer \& Selden (1998, p. 417) later described PSM as "the motivational force that induces individuals to perform meaningful public service". In other words, PSM is the motivational force that encourages individuals to do something meaningful in the public service. Afterwards, H. Rainey \& P. Shtaynbauer (1999) understood PSM as a common altruistic motivation of public servants [PA employees] who are ready to serve the interests of society, the state, nation or humanity.

In addition to motivation as an external factor that influences the effectiveness of the PA employees' professional work; we should also take into consideration the personal qualities of managers. Research papers devoted to governance are tradi- 
tionally focused on the concept of value (Kaufman \& Herbert, 1956). Researchers (Gilman et al., 1996) in this area identified the main types of values that were common to all cultures. They include ethical, democratic and professional values. M. Van Wart (1996) indicated five main value sources for public administration managers: personal, professional, organizational, legal and social interests. At the same time, the value of the "public interest" is the most important of the five listed.

Even though PA employees' values have not been determined, Ugur Omurgonulsen and M. Kemal Oktem (2009) pointed out the increasing role of the values of PA employees in public administration. This growth of recent trends in studying the integration of values into public administration has provoked considerable interest among PA scholars (Overeem \& Verhoef, 2014).

Per these two concepts, the aspects related to the organizational performance of public administration underlie the New Public Management paradigm, based on a new orientation towards the motivation and values of PA employees. In this respect, NPM involves creativity and innovation; from this perspective, the future application of Lean principles facilitates achieving performance in public administration.

In the transition to the new management model, the main provisions of which have been put forward and described in the second half of the last century (Osborn \& Gaebler, 1992), changes in the public administration should be aimed at optimizing the management of technology. NPM, a model that promotes new management values, is a new approach that significantly changes the development of activity in PA institutions and focuses on the new management coordinates, respectively objectives, results and responsibility. The flexibility in the performance of public tasks, provided in this model, suggests a need for the construction of a public administration system using Lean technologies. Consequently, it is very interesting to examine how the Lean process can reduce and eliminate losses in a continuous workflow within the organization (Wee \& Wu, 2009).

In determining the importance of public administration values, the values of the PA employees must be wider represented to understand the diversity of preferences, decision-making methods and behaviours of employees. Among the most known and used techniques to the study of individual values, it is necessary to highlight the research of Schwartz (1992), who developed the Schwartz Value Survey (SVS) and Portrait Values Questionnaire (PVQ), by testing just that. He singled out ten sets of personal values: hedonism, stimulation, autonomy, universalism, kindness, conformity, tradition, security, power and achievement. Then Schwartz (2012) added to the basic list nine other values having developed the Portrait Values Questionnaire-Revised (PVQ-R).

However, while Schwartz's individual values successfully describe the preferences of individuals, they may not accurately capture public administration values. Meanwhile, in addition to Schwartz' value theory, Rainey and Bozeman (1998) suggested that it is necessary to pay attention to both institutional relations and individual characteristics to determine the preferences of government officials. Thus, the authors comparing a bureaucratic model of personality and model of bureaucratic organization concluded that the choice of the sector of activities for employees in PA as bureaucratic personalities is a result of self-determination that is based on personal preferences. 
One of the most effective self-assessment tools that enable individuals to understand their own preferred type of thinking is the Herrmann Brain Dominance Instrument (HBDI) developed in the 1970s by Ned Herrmann. It emerged as a metaphor of validated the brain structures and includes four distinct thinking styles: analytical, organizational, strategic and interpersonal skills. The Four Quadrant Model, also known as Herrmann's Whole Brain Model, shows that the dominant thinking in one of four types of thinking leads to the development of thinking preferences. The findings of this model are summarized in Figure.

The Herrmann instrument considers how these preferences in thinking shape our interests and contribute to the development of competencies and influence career choices and, ultimately, performance functions. For this reason, it is necessary to classify target preferences in accordance with the system of PA employees' priorities. In this regard, a priority system can be expected to be consistent with the matrix management model, which is characterized by flexibility, innovation and the development of horizontal links between levels of government. Using the concept of priority in relation to the field of public administration assumes that the employees have certain personality traits and group characteristics explained by their behaviours both in choosing the profession and in the implementation of official duties.

\section{The Whole Brain Model \\ The Whole Brain Model}

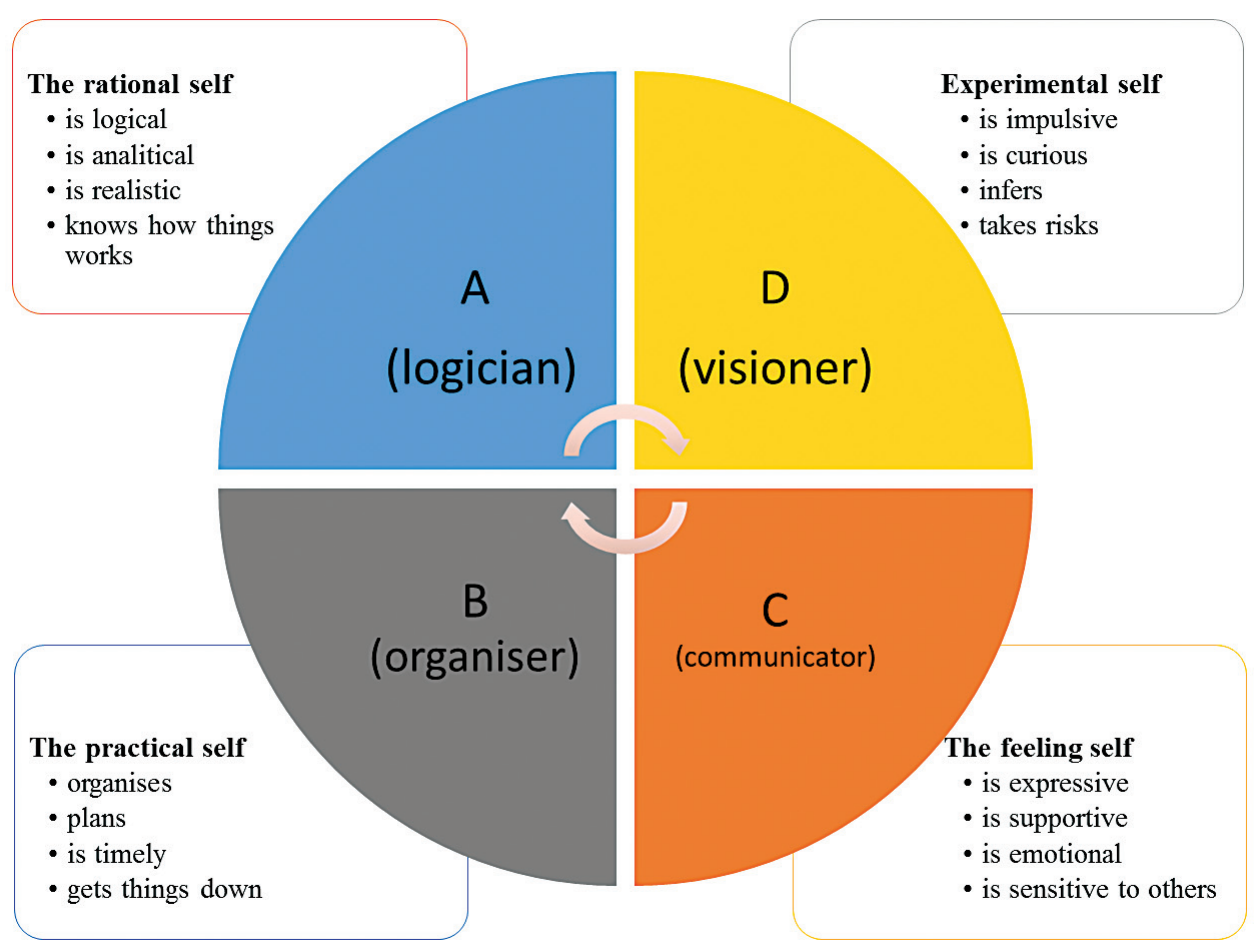

Adapted from: Hermann, 1996, 1996a; Kjærgaard et al., n.d, p. 9. 
Perhaps, one of the most important factors in the analysis of a PA employee's personal orientation is to study the motives for choosing his work. This sign, although it refers to the psychological factors, still helps to understand, based on from what personal motives the employee chooses a professional environment.

Table 2 provides the data that were collected via the survey of state and municipal employees from different Russian regions. All of the respondents participated in professional development programs in Russia. They were asked to think about their decision to pursue a career in PA and rank the survey questions, concerning the reasons (stability, PSM, salary, creativity, prestige), from 1 (low rank) to 5 (high rank). The survey was designed to identify personal preferences that allowed us to create profile of each PA employee. However, the indicator of prestige should be excluded from the analysis of personal preferences, because it cannot be an internal formed factor that motivates state and municipal employees to serve the public good.

The achieved survey sample consists of 276 respondents predominantly from regional authorities (52\%), federal body (33\%) and local government (15\%). In all, the average age of respondents is in the range of 25 to 34 years, and the average level of education is at the level of higher education. The gender distribution of the respondents was uniform; however, women are slightly dominated.

As expected, the results indicate that the distribution of factors that affect the value and motivational aspects of PA employee personality have some tendentiousness, which can be noticed by drawing attention to the data summarized in Table 2. Most of the public administration employees work in the public sector, because of the stability of a social position within the public service. In this regard, the participants in the survey singled out stability as their main incentive, that is indeed the determining factor in choosing a place of work during the crisis time both for women and for men. Further, in the opinion of government body employees, motivation also plays a big role, especially for middle-aged professionals. Creativity is a less significant factor, and the lowest ranked in attractiveness for public administration employees is remuneration of labour.

These four most obvious values and motivational characteristics in the sphere of public administration should be identified as the main types of PA employees' priorities. Within the framework of the value-motivational approach to personal qualities, we outlined the following priority groups, which also correspond with the four preferences profiles in Herrmann's Whole Brain Model (Hermann, 1996, 1996a; Herrmann \& Herrmann-Nehdi, 2015):

- Organizational priorities (the practical self-priorities related to the duties of PA employees, who are mainly willing to receive material incentives for their implementation);

- Official priorities (the rational self-priorities appeared in the process of working in the state, region or municipal authority as in the organization characterized by stability);

- Promotion priorities (the feeling self-priorities allocated based on motivational theory, where material and moral incentives are in the form of incen- 
tives that motivate public administration employees to work effectively and make correct decisions);

- Initiative priorities (the experimental self-priorities based on the internal motivation of a public servant to demonstrate his personal creativity skills to be more practical oriented).

Table 2

\section{Social and demographic characteristics and personal preferences of the respondents}

\begin{tabular}{|c|c|c|c|c|c|c|c|c|}
\hline \multicolumn{4}{|c|}{ Social and demographic characteristics } & \multicolumn{5}{|c|}{ Preferences } \\
\hline Gender & Age & Education & Position & Stability & PSM & Salary & Creativity & Prestige \\
\hline \multirow[t]{15}{*}{ Female } & $18-24$ years & $\begin{array}{l}\text { higher } \\
\text { education }\end{array}$ & Specialist & 4.40 & 1.20 & 2.20 & 2.20 & 3.80 \\
\hline & $25-34$ years & $\begin{array}{l}\text { graduate } \\
\text { school }\end{array}$ & Advisor & 3.00 & 4.00 & 1.00 & 2.00 & 5.00 \\
\hline & & $\begin{array}{l}\text { higher } \\
\text { education }\end{array}$ & Manager & 4.82 & 2.27 & 2.18 & 1.82 & 3.91 \\
\hline & & & Specialist & 4.48 & 2.26 & 2.15 & 1.96 & 4.15 \\
\hline & & $\begin{array}{l}\text { more than } \\
\text { one higher } \\
\text { education }\end{array}$ & Manager & 5.00 & 3.00 & 4.00 & 1.00 & 2.00 \\
\hline & & & Specialist & 4.75 & 1.88 & 2.75 & 3.13 & 2.50 \\
\hline & $35-44$ years & $\begin{array}{l}\text { graduate } \\
\text { school }\end{array}$ & Manager & 1.00 & 5.00 & 3.00 & 4.00 & 2.00 \\
\hline & & $\begin{array}{l}\text { higher } \\
\text { education }\end{array}$ & Advisor & 3.00 & 5.00 & 2.00 & 4.00 & 1.00 \\
\hline & & & Manager & 3.67 & 3.22 & 1.44 & 3.33 & 3.33 \\
\hline & & & Specialist & 4.25 & 2.00 & 2.75 & 2.00 & 3.75 \\
\hline & & $\begin{array}{l}\text { more than } \\
\text { one higher } \\
\text { education }\end{array}$ & Specialist & 4.00 & 3.00 & 1.00 & 2.00 & 5.00 \\
\hline & $45-54$ years & $\begin{array}{l}\text { graduate } \\
\text { school }\end{array}$ & Advisor & 5.00 & 2.00 & 4.00 & 3.00 & 1.00 \\
\hline & & $\begin{array}{l}\text { higher } \\
\text { education }\end{array}$ & Manager & 4.27 & 2.00 & 3.27 & 2.82 & 2.64 \\
\hline & & & Specialist & 4.70 & 3.70 & 2.20 & 2.00 & 2.40 \\
\hline & 55 or older & $\begin{array}{l}\text { higher } \\
\text { education }\end{array}$ & Specialist & 4.00 & 4.00 & 2.00 & 2.00 & 3.00 \\
\hline \multicolumn{4}{|c|}{ Total results (female respondents) } & 4.02 & 2.97 & 2.40 & 2.48 & 3.03 \\
\hline \multirow[t]{2}{*}{ Male } & $18-24$ years & $\begin{array}{l}\text { higher } \\
\text { education }\end{array}$ & Specialist & 4.50 & 2.50 & 3.25 & 1.25 & 3.50 \\
\hline & $25-34$ years & $\begin{array}{l}\text { graduate } \\
\text { school }\end{array}$ & Manager & 4.00 & 2.00 & 5.00 & 3.00 & 1.00 \\
\hline
\end{tabular}




\begin{tabular}{|c|c|c|c|c|c|c|c|c|}
\hline \multicolumn{4}{|c|}{ Social and demographic characteristics } & \multicolumn{5}{|c|}{ Preferences } \\
\hline Gender & Age & Education & Position & Stability & PSM & Salary & Creativity & Prestige \\
\hline & & $\begin{array}{l}\text { higher } \\
\text { education }\end{array}$ & Advisor & 1.00 & 3.00 & 2.00 & 5.00 & 4.00 \\
\hline & & & Assistant & 5.00 & 1.00 & 2.00 & 3.00 & 4.00 \\
\hline & & & Manager & 3.08 & 3.15 & 2.08 & 3.77 & 2.92 \\
\hline & & & Specialist & 3.20 & 3.13 & 1.67 & 2.87 & 2.13 \\
\hline & & $\begin{array}{l}\text { more than } \\
\text { one higher } \\
\text { education }\end{array}$ & Manager & 3.00 & 4.75 & 1.75 & 4.25 & 1.25 \\
\hline & & & Specialist & 4.00 & 5.00 & 2.00 & 1.00 & 3.00 \\
\hline & $35-44$ years & $\begin{array}{l}\text { graduate } \\
\text { school }\end{array}$ & Manager & 5.00 & 3.50 & 2.50 & 2.25 & 1.75 \\
\hline & & & Specialist & 1.50 & 5.00 & 0.50 & 2.00 & 1.00 \\
\hline & & $\begin{array}{l}\text { higher } \\
\text { education }\end{array}$ & Manager & 2.82 & 2.00 & 0.73 & 2.73 & 2.64 \\
\hline & & & Specialist & 3.00 & 2.70 & 2.10 & 1.60 & 3.20 \\
\hline & & $\begin{array}{l}\text { more than } \\
\text { one higher } \\
\text { education }\end{array}$ & Manager & 1.20 & 2.40 & 0.60 & 3.00 & 1.80 \\
\hline & & & Specialist & 5.00 & 4.00 & 1.00 & 3.00 & 2.00 \\
\hline & $45-54$ years & $\begin{array}{l}\text { graduate } \\
\text { school }\end{array}$ & Manager & 5.00 & 4.00 & 3.00 & 1.00 & 2.00 \\
\hline & & $\begin{array}{l}\text { higher } \\
\text { education }\end{array}$ & Manager & 3.00 & 5.00 & 2.00 & 4.00 & 1.00 \\
\hline & & & Specialist & 4.00 & 3.00 & 1.00 & 5.00 & 2.00 \\
\hline & & $\begin{array}{l}\text { more than } \\
\text { one higher } \\
\text { education }\end{array}$ & Manager & 2.00 & 5.00 & 1.00 & 4.00 & 3.00 \\
\hline & & & Specialist & 5.00 & 3.00 & 4.00 & 2.00 & 1.00 \\
\hline & 55 or older & $\begin{array}{l}\text { graduate } \\
\text { school }\end{array}$ & Manager & 2.00 & 5.00 & 4.00 & 3.00 & 1.00 \\
\hline & & $\begin{array}{l}\text { higher } \\
\text { education }\end{array}$ & Manager & 5.00 & 2.63 & 2.75 & 1.00 & 3.63 \\
\hline & & & Specialist & 3.29 & 3.29 & 1.71 & 1.29 & 0.86 \\
\hline & & $\begin{array}{l}\text { more than } \\
\text { one higher } \\
\text { education }\end{array}$ & Manager & 3.00 & 5.00 & 1.00 & 4.00 & 2.00 \\
\hline & & & Specialist & 5.00 & 0.00 & 3.00 & 2.00 & 4.00 \\
\hline Total res & ts (male respo & adents) & & 3.48 & 3.34 & 2.11 & 2.75 & 2.28 \\
\hline Total Re & & & & 3.83 & 2.92 & 2.20 & 2.53 & 2.82 \\
\hline
\end{tabular}


The overall findings from the survey support the authors' initial hypotheses predicting that officials' priorities are formed in the awareness of PA employees of their professional performance in the public service. The most valuable for all employees were official priorities, and therefore the main factors that determined their entry into service were internal values and motives regarding the importance of work stability in the state, region or municipal authority.

Based on some of the approaches (mentioned above) in the field of state and municipal services it should be concluded that the development of such a social body as a public administration requires a reassessment of the role of factors that influence the expression of the personality and create behaviour.

The authors of the present paper studied various classifications of personal preferences that could be used for selecting employees for the job. According to Lean thinking, project team members need to represent all preferences to be more successful. However, personal preferences cannot be the employees' only selection criteria, because the basic criteria are employees' competences.

\section{Public administration employees' competences}

Besides personal preferences, it is important to consider the competences of public administration employees during the process of selection, performance appraisal, motivation etc. PA practitioners use a competence-based approach (Spenser \& Spenser, 1993) in human resource management processes. The authors, considered previous research on PA employees' competences (Starineca \& Voronchuk, 2015; Starineca \& Voronchuk, 2016) and the example of a competence-based approach in the cases of both Latvia (Ministru kabinets, 2012) and Russia (Ministerstvo truda i..., 2013).

Competences might be grouped, and competences models might be developed specifically for different levels of PA employees or even for a certain PA organisation project group/team. There are various dimensions of competences (Cheetham \& Chivers, 1996, 1998; Delamare Le Deist \& Winterton, 2005):

- Cognitive;

- Functional;

- Personal (behavioural);

- Ethical;

- Meta-competencies.

PA organisations need to define which competence is important for a certain position and define a level of competence to compare it with the level of competence that a job candidate or employee has. Definitions of the competences can vary as well as their groups. In the case of the Latvian PA, employees' competences groups are (Ministru kabinets, 2012):

1. Communication and collaboration;

2. Thinking and problem solving;

3. Personal contribution;

4. Task and process management;

5. Heads competence;

6. Authority's values understanding. 
In the case of Russia, the groups of competences are (Ministerstvo truda i..., 2013):

1. General professional;

2. Applied professional;

3. Managerial.

Each competence from the group is combined with other group competences for the certain level of position in PA and the combination might be different for each position. The specific level of competence necessary to fulfil the certain tasks also differs. For example, the ICB framework offers access to the technical, behavioural and contextual competence elements of project management' that is called the eye of competence (International Project Management..., 2006). This model has been developed for a project manager.

In the case of Latvia, the human resource department heads of the ministries who participated in the survey highlighted as important competences for ministry employees such competences from the list of the Tuning - PA project (2014) as (Starineca \& Voronchuk, 2016):

- Analyse and solve problems from the perspective of third parties, particularly politicians, professionals, citizens and representatives of civil organisations;

- Be familiar with research development in the respective policy field;

- Communicating and interacting in an intercultural context;

- Communication with politicians, experts, citizens, and representatives of civil organisations;

- Compare and evaluate different PA systems;

- Conduct applied research with regards to a given problem;

- Consideration of problems from different disciplinary perspectives;

- Cooperating in multidisciplinary teams;

- Evidence-based decision making, interpreting and applying policy agendas, anticipating future trends in public service, and adapting activities to suit specific public services contexts;

- Formulation advice to important stakeholders;

- Handle problems with regards to the economic, political, legal and sociologic reality;

- Incorporate public service ethics and public values;

- Make use of the theoretical knowledge of the PA-related disciplines to analyse and solve problems in the public domain;

- Negotiation with politicians, experts, citizens, and representatives of civil organisations;

- Networking and cooperation with other organisations;

- Policy implementation;

- Select and apply appropriate methods, techniques and tools to analyse and solve a problem;

- Understand the disciplines dealing with public administration;

- Understanding social, political and economic development;

- Use methods and techniques of socio-scientific research, including statistics;

- $\quad$ Use the results of research for decision-making or policy proposals.

PA employees' competences need to be developed based on their level evaluation.

In the case of Latvia, a special system called NEVIS exists that allows for the evaluation 
of the competences of current employees, so each employee has a profile with a list of competences necessary for the job (Ministru kabinets, 2012; Baltic Institute of..., 2015).

In selecting a project team member, a list of necessary competences might include different types of competences that are relevant in both project implementation and work for a PA organisation at a certain level.

The competence-based approach is topical and relevant for various HRM process implementation in public administration organisations as well as in private ones. However, both the personal preferences of the employees and their relevance to the job competences need to be considered when developing a productive, efficient working environment. This statement is also supported by the survey data that is based on the replies of the potential current and future employees of the public administration organisations. It is important to evaluate current and potential future employees' requirements of the workplace, the conditions, and the employer. The possibility to use and develop competences also depends on the opportunity given by the employer, including working conditions and satisfaction of personnel preferences of the employees. For example, the rather important and very important characteristics of work content highlighted by the students and recent graduates of Latvia who participated in the survey by the "Baltic Institute of Social Sciences" Foundation and “O.D.A.” Ltd. are (Baltic Institute of..., 2015):

1. Interesting work;

2. Work in which an employee feels that (s)he can achieve something;

3. Work that matches the abilities of the employee;

4. Explicit work tasks;

5. Work where an employee can learn new skills etc.

According to the survey, work where employees are free to plan their working hours and their day is important in just 38\% of the cases, however, these characteristics are quite important for the respondents.

One more survey considered by the authors reflects employers requirements of Latvian PA study programs students. Advancement opportunities and working environment are at the top of the list of important elements that influence employers' decisions regarding applications for job offers (Starineca, 2017).

The importance of a complex approach to the selection of human resources including project team members, and to ensure the successful fulfilment of a task or the successful implementation of a project, has been supported in Chapter 3 and the empirical data reflected in Chapters 4 and 5. This evidence was a base for development of the model for project team members' selection.

\section{A Model for Project Team Members' Selection}

When selecting project team members, it is useful to have a matrix organisational structure, especially in the case of regular project activity within the organisation. A public administration organisation that implements Lean needs to consider the specific approach to optimise resources and ensure successful project fulfilment that is influenced by a project team. The authors of the paper propose a model for project team members' selection considering both the competences and personal preferences of employees (Appendix). 
1. When a team for a project needs to be staffed, the first task that needs to be fulfilled is definition of the number of employees $(E, 1 \leq E \leq r, E=1,2, \ldots, r)$ needed and this can then be allocated by the organisation departments for the project implementation. Thus, a document with the allocated employees and their profiles will be created. The profiles can be retrieved from the HR/ personnel database of the organisation. The profiles need to include data on the employees' competences and their levels as well as their personal preferences (Hermann, 1996; Kjærgaard et al., n.d., pp. 8-9). The database can be connected to the employees' assessment system (e.g. such as NEVIS (Ministru kabinets, 2012) in Latvia that is used to assess public administration organisations employees' performance). Employees' profiles need to have numerical competences assessment results. The system also needs to have personal preferences test(s) results emphasizing the main (one out of four) personal preference of the employee. As preferences and levels of competences might change, the test(s) and competences assessment need to be implemented periodically.

2. The project team recruiters need to be aware of the necessary team members' roles and tasks, therefore they would be able to define the competences necessary to implement the project. This is the second step of the selection process (preparation for the selection activities). Besides the necessary competences, other selection criteria might also be defined e.g. age of experience working with certain tasks or in a certain field, level of a certain language knowledge and other abilities that are not directly included in the set list of the competences that might usually be assessed via e.g. the employees' performance assessment system. An important detail that needs to be highlighted is the necessity for other criteria evaluation using the same numerical evaluation scale i.e. if the competences are assessed using a 5-point scale, other criteria need to be assessed using a 5-point scale too.

3. The third step would be the comparison of all competences and criteria by importance level necessary for the project implementation. The level of importance needs to be split between all criteria and competences proportionally. A pair-wise comparison can be implemented to fulfil this task using, for example, Saaty's 9-point linear scale (Coyle, 2004).

4. When the evaluation criteria and the candidates (allocated employees) profiles with necessary data are prepared, the evaluation can be started. The fourth step presumes the certain calculation using equation (1).

$$
\sum_{j=1}^{n} a_{i j} b_{j}
$$

where

1) $i$ - an employee/ candidate number (code), $1 \leq i \leq m(i=1,2, \ldots, m)$

2) $j$ - a competence number (code), $1 \leq j \leq n(j=1,2, \ldots, n)$

3) $b_{j}$ - a proportion of a competence $j$ by importance level, $0 \leq b_{j} \leq 1$; the sum of proportion of each competence should be equal to 1 (2)

4) $a_{i j}$ - numerical level of a competence $j$ of an employee/ candidate $i, k \leq a_{i j} \leq l$, where $k$ and $l$ are determined by organisation or a normative act, which regulates the competences numerical assessment scale's range. 


$$
\sum_{j=1}^{n} b_{j}=1
$$

5. The fifth step includes the sorting of the employees/ candidates by the score got based on the calculations fulfilled in step four. The recruiters can create a list/ rating of the employees/ candidates with the highest score. Inclusion of the employees/ candidates can be based on the number of the employees needed $(E)$ that is more suitable in case, when a number of the employees/ candidates allocated or applied for the competition (if internal recruitment and application is acceptable and possible; usually it is possible in the larger structured organisations) $e(1 \leq \mathrm{e} \leq u, e=1,2, \ldots, u)$ is more than $E$ (i.e. e $>E$ ) or based on the minimal acceptable score defined $(d, k<d<l$, because it is doubtful that a minimal score to be included in the rating could be $k$ (the minimal possible) or $l$ (the maximal possible). In the first case, the top $E$ with the highest score is selected. In the second case, employees/ candidates are selected, if they meet the criterion (3).

$$
\sum_{j=1}^{n} a_{i j} b_{j} \geq d
$$

5.1. If number of the preselected employees is less than the number of the employees needed $(E)$, it is necessary to outsource candidates (have an external recruitment).

5.2. Having outsourced applicants (candidates), it is necessary to test them, assessing their competences and abilities (if applicable) that are needed to work on the project and define their personal preferences. Having a list with the outsourced candidates and their profiles, the selection process can then be continued from step four.

6. If number of the preselected employees is greater than needed for the project $(E)$, the final selection step can be made. It is selection of the number of the employees needed $(E)$ with the highest rating score having at least one representative from each personal preference group present. It is time to split employees/ candidates to four groups by their personal preference. It might happen that there are employees/ candidates, who represent only a few out of the four groups by personal preferences. The task is to have the maximally diverse team possible with the maximal summed score (calculated applying mathematical approach (linear programming) to solve optimisation problem (4).

$$
\begin{gathered}
\sum_{j=1}^{n} a_{i j} b_{j}=A_{i} \\
\sum_{z=1}^{4} A_{i z} x_{i z} \rightarrow \max ,
\end{gathered}
$$

where

1) $A_{i}$ is a rating score of an employee/ candidate $i$ preselected;

2) $A_{i z}$ is a rating score of an employee/ candidate $i$ preselected, who has a personal preference $z(z=1,2,3,4)$; 
3) $x_{i z}$ is an indicator that shows, if an employee/ candidate $i$ preselected, who has a personal preference $z$, is selected as a project team member, $0 \leq x_{i z} \leq 1$, so $x_{i z}$ is binomial and integer (5); if $x_{i z}=0$, it means that the employee/ candidate $i$ preselected, who has a personal preference $z$, is not selected as a project team member, if $x_{i z}=1$, the employee/ candidate $i$ is selected as a project team member.

Satisfying an objective function (4), some limitations should be considered. First, it is necessary to identify $z$. Each out of four personal preferences $z$ is coded by a number from 1 to 4 . If there is no employee/ candidate preselected that has any of the preferences $z$, this preference $\mathrm{z}$ is excluded from the further calculations, i.e. if there are employees/ candidates with only three out of four preferences, $1 \leq z \leq 3(z=1,2,3)$. Secondly, limitations (5) need to be considered.

$$
\left\{\begin{array}{l}
\sum_{i=1}^{m} x_{i z} \geq 1 \\
\sum_{z=1}^{4} x_{i z}=E
\end{array} 0 \leq x_{i z} \leq 1, x_{i z}=\text { bin, } x_{i z}=i n t,\right.
$$

where

$E$ is number of employees needed for the project implementation $1 \leq E \leq r$, $E=1,2, \ldots, r$.

7. The final step is a check of the selected employees/ candidates by personal preferences.

8. If $1 \leq z<4$, it is necessary to define possible risks and challenges that might appear because of the lack of team members with the certain professional preference(s) to be ready to overcome these challenges (Starineca, 2016).

The project team is staffed and analysed by strength and weaknesses. During the project implementation team members could support each other by being mentors of each other in the certain field that will help them to be involved in a lifelong learning process and develop their competences.

The model is applicable in cases when an organisation selects project team members separately by roles. In this case, $E_{p}$ is the number of employees needed for the certain role $p$, but $e_{p}$ is the number of employees allocated for the certain role $p$ or who have applied for it (if internal recruitment and application is acceptable and possible; usually it is possible in the larger structure organisations). Thus, each other defined value $a, b$ and $d$ will be defined for the certain role $p$.

Sometimes outsourcing is difficult to implement or impossible for a PA organisation, therefore it is necessary to consider that $E \leq e$. If this imparity is not true from the beginning, the recruiters need to optimize project work and split project team roles and responsibilities between the maximally available number of employees and change $\mathrm{E}$ value, so it is $\mathrm{E} \leq \mathrm{e}$ to start the selection process. It is necessary to do this even if outsourcing is possible because $\mathrm{E}$ is the number of employees that are needed and could be potentially allocated.

When teaching a Human Resource Management course to Public Administration program students, the proposed model can be demonstrated as an example of the rational project team selection approach for a Public Administration organisation implementing Lean (Starineca, 2017). 


\section{Conclusion}

The development of such a social body as a public administration requires a reassessment of the role of the factors that influence the expression of the personality and create behaviour. The possibility to use and develop competences also depends on the opportunity given by the employer including working conditions and satisfaction of personnel preferences of the employees. For a project's successful implementation, it is important to consider a complex approach to the selection of project team members.

The developed tool is more suitable for large organisations that may afford to assign different department members to work on certain ongoing internal projects. Each company needs to evaluate if it can afford to apply human resource outsourcing in cases where a lack of competent employees are allocated for work on a project. The tool helps to increase the efficiency of a project team by selecting the most competent employees from the pool and creating a balanced team by their personal preferences as much as possible. It can be a base for a software or a function integrated into existing software that connects an organisation's human resource management system. The system should have information on employees' professional profiles i.e. a database with a list of competences and personal preferences of each employee. The level of the competences needs to be periodically assessed (performance appraisal) and updated in the database.

The model has not been tested yet. Testing and evaluation of the examination may be a base for further studies.

\section{REFERENCES}

1. Bailey, S.K. (1964). Ethics and the Public Service. Public Administration Review, vol. 24, no 4, pp. 234-243.

2. Baltic Institute of Social Sciences and O.D.A. (2015). The Study on the Future Role and Development of the Public Administration Summary. Available at: http://www.mk.gov. $\mathrm{lv} / \mathrm{sites} /$ default/files/editor/the_study_on_the_future_role_and_development_0.pdf (accessed: March 20, 2017).

3. Bozeman, B. \& Rainey, H.G. (1998). Organizational rules and the "bureaucratic personality". American Journal of Political Science, vol. 42, no 1, pp. 163-189.

4. Brewer, G.A. \& Selden, S.C. (1998). Whistle Blowers in the Federal Civil Service: New Evidence of the Public Service Ethic. Journal of Public Administration Research and Theory, vol. 8, no 3, pp. 413-440.

5. Christiansen, T.B., Ahrengot, N. \& Leck, M. (2012). Lean: Implementering i Danske Virksomheder. Børsen.

6. Coyle, G. (2004). Practical Strategy: The Analytic Hierarchy Process (AHP). Glasgow: Pearson Education Limited.

7. Demmke, C. (2005). Are Civil Servants Different because they are Civil Servants? (pp. 1-127). Présidence luxembourgeoise du Conseil de l'Union européenne. 
8. Diefenbach, T. (2009). New Public Management in Public Sector Organisations: The Dark Sides of Managerialistic 'Enlightement'. Public Administration, vol. 87, no 4, pp. 892-909.

9. Gilman, S.C. \& Lewis, C.W. (1996). Public Service Ethics: A Global Dialogue. Public Administration Review, vol. 56, no 6, pp. 517-524.

10. Graham, G.A. (1952). Morality and Administration in Democratic Government. By Paul H. Appleby. (Baton Rouge: Louisiana State University Press). 1952. Pp. xiii, 261). American Political Science Review, vol. 46, no 04, pp. 1175-1177.

11. Hermann, N. (1996). The Whole Brain Business Book. New York: McGraw-Hill.

12. Herrmann, N. (1996a). The Whole Brain Business Book: Unblocking the Power of Whole Brain Thinking in Organizations and Individuals. New York, San Francisco, Washington DC, Auckland, Bogota, Caracs, Lisbon, London, Madrid, Mexico City, Milan, Montreal, New Delhi, San Juan, Singapore, Sydney, Tokyo, Toronto: McGraw-Hill, pp. 6-19.

13. Herrmann, N. \& Herrmann-Nehdi, A. (2015). The Whole Brain Business Book: Unlocking the Power of Whole Brain Thinking in Organizations, Teams, and Individuals. McGraw Hill Professional.

14. International Project Management Association. (2006). ICB. IPMA Competence Baseline Version 3.0. International Project Management Association. Available at: http://www.lpva.lt/cms/ files/lpva/resources/4640_IPMA_ICB_EN.pdf (accessed: 31 January, 2015).

15. Kaufman, H. (1956). Emerging Conflicts in the Doctrines of Public Administration. American Political Science Review, vol. 50, no 04, 1057-1073.

16. Kjærgaard, J., Bogason, A., Implement Consulting Group, \& Jensen, J. Ø. (n.d.). Lean in Public Administration. Implement Consulting Group. Available at: http://implementconsultinggroup.com/media/2509/lean-in-public-administration.pdf (accessed: 15 March, 2017).

17. Lean Enterprise Institute, Inc. 2000-2017. What is Lean? Available at: https://www.lean.org/ WhatsLean/ (accessed: 21 March, 2017).

18. Ministerstvo truda i sotsial'noy zashchity Rossiyskoy Federatsii (2013). Metodicheskiy instrumentariy po vnedreniyu sistemy kompleksnoy otsenki professional'noy sluzhebnoy deyatel'nosti gosudarstvennykh grazhdanskikh sluzhashchikh (vklyuchaya obshchestvennuyu otsenku) [Methodological Tools for Implementing a Comprehensive Assessment of Professional Performance of Public Civil Servants (Including Public Evaluation)]. Available at: http://www. rosmintrud.ru/ministry/programms/gossluzhba/4/Ocenka.docx (accessed: 14 March, 2015).

19. Ministru kabinets (2012). Noteikumi par valsts tiešās pārvaldes iestādēs nodarbināto darba izpildes novērtēěanu. Available at: http://likumi.lv/doc.php?id=250211 (accessed: 15 March, 2017).

20. Omurgonulsen, U. \& Oktem, M. K. (2009). Is there any Change in the Public Service Values of Different Generations of Public Administrators? The Case of Turkish Governors and District Governors. Journal of Business Ethics, vol. 88, no 1, pp. 137-156.

21. Osborne, D. \& Gaebler, T. (1992). Reinventing Government: How the Entrepreneurial Spirit is Transforming Government. Reading Mass. Adison Wesley Public Comp.

22. Overeem, P. \& Verhoef, J. (2014). Moral Dilemmas, Theoretical Confusion: Value Pluralism and its Supposed Implications for Public Administration. Administration \& Society, vol. 46, no 8, pp. 986-1009.

23. Pedersen, E.R.G. \& Huniche, M. (2011). Negotiating Lean. The Fluidity and Solidity of New Management Technologies in the Danish Public Sector. International Journal of Productivity and Performance Management, vol. 60, no 6, pp. 550-566. 
24. Perry, J.L. \& Wise, L.R. (1990). The Motivational Bases of Public Service. Public Administration Review, vol. 50, no 3, pp. 367-373.

25. Pick, D. \& Teo, S.T.T., 2017. Job Satisfaction of Public Sector Middle Managers in the Process of NPM Change. Public Management Review, vol. 19, no 5, pp. 705-724.

26. Rainey, H.G. \& Steinbauer, P. (1999). Galloping Elephants: Developing Elements of a Theory of Effective Government Organizations. Journal of Public Administration Research and Theory, vol. 9, no 1, pp. 1-32.

27. Schwartz, S.H. (1992). Universals in the Content and Structure of Values: Theoretical Advances and Empirical Tests in 20 Countries. Advances in Experimental Social Psychology, no 25 , pp. 1-65.

28. Schwartz, S.H., Cieciuch, J., Vecchione, M., Davidov, E., Fischer, R., Beierlein, C., ... \& DirilenGumus, O. (2012). Refining the Theory of Basic Individual Values. Journal of Personality and Social Psychology, vol. 103, no 4, pp. 663.

29. Starineca, O. (2016). Competence-Based Approach Implementation Tool for Project Team Members Selection. Scientific Conference on Economics and Entrepreneurship (SCEE'2016) devoted to the 50th Anniversary of the Faculty of Engineering Economics and Management. Proceedings, pp. 73-74.

30. Starineca, O. (2017). Holistic Approach to Human Resource Recruitment and Selection for Public Administration Organisations of Latvia. University of Latvia. Ph.D. diss., University of Latvia.

31. Starineca, O. \& Voronchuk, I. (2015). Competence-Based Selection of Project Team Members - General Approach. Project Management Development - Practice and Perspectives. Riga, pp. 363-374.

32. Starineca, O. \& Voronchuk, I. (2016). Public Administration Study Programs Development Based on Employers Competences Requirements: Matrix System of Occupations and Competences. Proceedings of the 24nd NISPAcee Annual Conference, NISPAcee PRESS, pp. 1-13.

33. Tuning-PA project. (2014). Tuning-PA project: Generic Competences, Questionnaire for Academics. European Association for Public Administration Accreditation (EAPAA), the Network of Institutes and Schools of Public Administration in Central and Eastern Europe (NISPAcee), and the European Group for Public Administration (EGPA). Available at: https://docs.google. $\mathrm{com} /$ spreadsheet/viewform?formkey=dGc3V19vMzlIUDJXRVVXQmhETHFfQnc6MA\# gid=0;https://sites.google.com/site/tuningpaproject/ (accessed: 1 August, 2014).

34. Urmoniené, D. \& Žukovskis, J. (2013). Application of Good Governance Model in the Municipalities: The Case of Lithuania. Proceedings of the International Scientific Conference: Rural Development, pp. 6647-652.

35. Van Wart, M. (1996). The sources of ethical decision making for individuals in the public sector. Public Administration Review, vol. 56, no 6, pp. 525-533.

36. Voronchuk, I. \& Starineca, O. (2014). Knowledge Management and Possibilities of Professional Development in Public Sector. European Integration Studies, no 8, pp. 168-179.

37. Wagenaar, H. (1999). Value Pluralism in Public Administration. Administrative Theory \& Praxis, vol. 21, no 4, pp. 441-449.

38. Wee, H.M. \& Wu, S. (2009). Lean Supply Chain and its Effect on Product Cost and Quality: A Case Study on Ford Motor Company. Supply Chain Management: An International Journal, vol. 14, no 5, pp. 335-341.

39. Womack, J.P. \& Jones, D.T. (2003). Lean Thinking. 2nd Edition. Simon \& Schuster, Inc. 


\section{APPENDIX}

A proposed model of a Public Administration organisation project team members' selection process implementing Lean

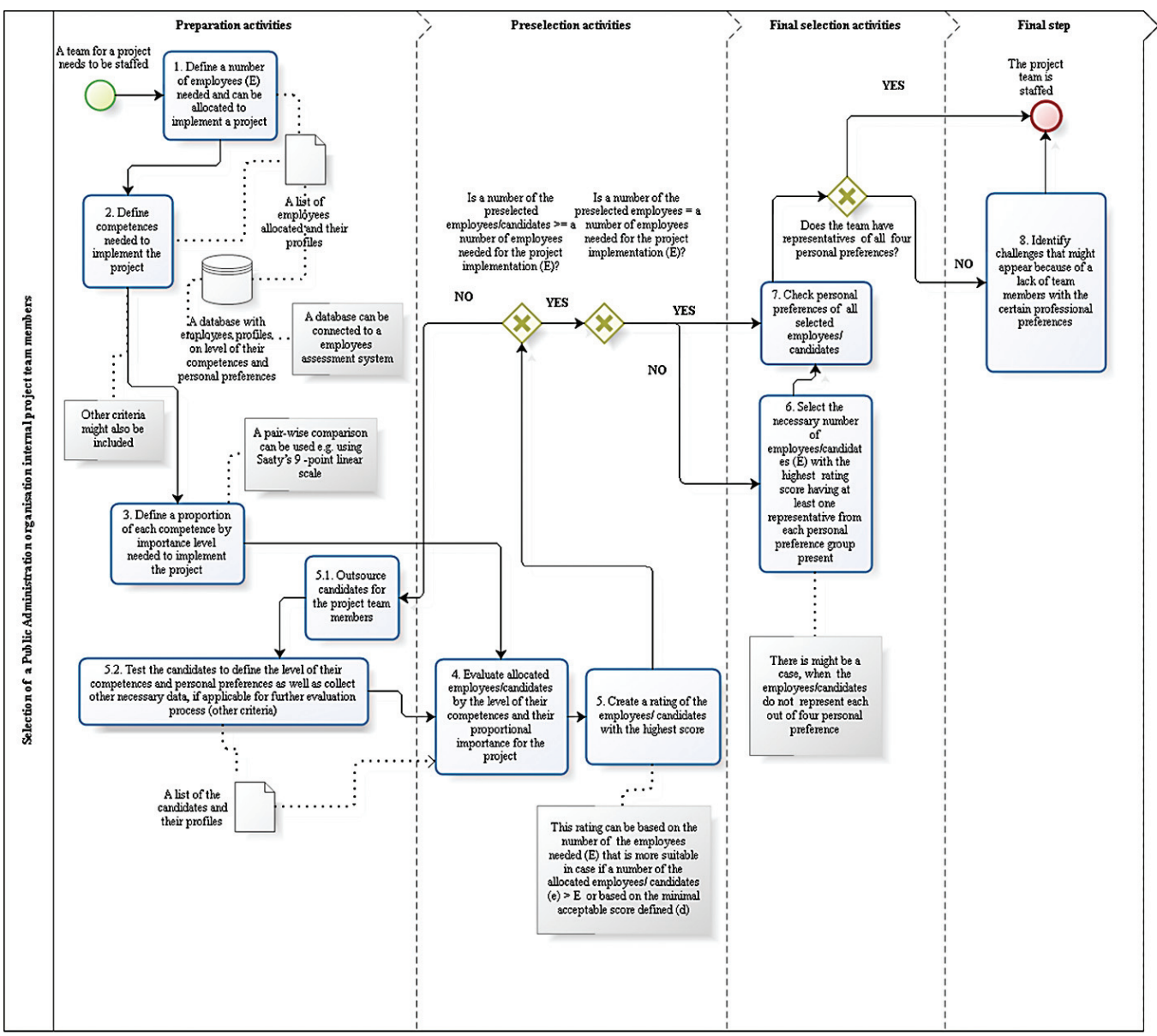

Adapted from Stariņeca, 2017. 